\title{
LABORATORY AND COMMERCIAL-SCALE EVALUATION OF THE EFFECT OF PURE AND COMMERCIAL ENDOXYLANASES AND ENDOGLUCANASES ON WHEAT FLOUR BREAD QUALITY
}

\author{
C. Roets ${ }^{\mathrm{a}}$, S.H. Rose ${ }^{\mathrm{b}}$, M. MulLeR ${ }^{\mathrm{a}}$ and M. MANLeY ${ }^{\mathrm{a} *}$ \\ ${ }^{\mathrm{a}}$ Department of Food Science, Stellenbosch University, Private Bag X1, Matieland (Stellenbosch), \\ 7602. South Africa \\ ${ }^{b}$ Department of Microbiology, Stellenbosch University, Private Bag X1, Matieland (Stellenbosch), \\ 7602. South Africa
}

(Received: 21 November 2013; accepted: 13 February 2014)

\begin{abstract}
The effect of a pure endoxylanase (Xyn2) and endoglucanase (EgII) from Trichoderma reesei on bread flour quality were compared to a commercial endoxylanase from Aspergillus niger (Com-xyl) and a cellulase-xylanase cocktail from T. reesei (Cel-xyl). Effects of these enzymes on dough quality, bread weight, height and crumb softness were analysed. Results obtained during commercial-scale baking tests often differed from those obtained during laboratory-scale tests; indicating that results from laboratory-scale baking tests cannot be extrapolated to commercialscale bread production. Low levels of endoxylanase activity benefited bread height and volume without affecting slice brightness in commercial-scale tests. The addition of endoglucanases and $\alpha$-amylases can also be advantageous resulting in less endoxylanase activity required to obtain similar results.
\end{abstract}

Keywords: endoxylanase, endoglucanase, wheat flour, bread quality, laboratory-scale, commercial-scale

Bread, the staple diet of many cultures around the world, is made primarily of wheat flour. The general composition of wheat flour is 70 to $75 \%$ starch, $14 \%$ water, 10 to $12 \%$ protein, 2 to $3 \%$ arabinoxylans (AX) and $2 \%$ lipids (GOESAERT et al., 2005). Wholemeal wheat flour can contain up to 5\% AXs (BAILLET et al., 2003). Up to 75\% of dry weight of wheat endosperm cell walls consists of non-starch polysaccharides (NSPs) of which AX are by far the most prominent group $(85 \%)$. AX can be divided into water-extractable (WE-AX) and waterunextractable fractions (WU-AX), with the WU-AX fractions constituting between 70 and $75 \%$ of total AX (Courtin \& Delcour, 2002).

Cellulose is one of the lesser constituents of NSPs in wheat flour (HILLE, 2005) and not believed to play a significant role in the bread making process. Cellobiohydrolases, endoglucanases and $\beta$-glucosidases (collectively known as cellulases) are known to synergistically degrade the cellulose structure, resulting in the release of glucose (ARISTIDOU \& Penttilä, 2000; Hille, 2005). AX is partly intertwined with cellulose, therefore, requiring cellulases to hydrolyse the cellulose to ease access to the AX (HILLE, 2005). Microbial derived endoxylanases are able to hydrolyse the AX backbone internally, releasing oligosaccharides (Goesaert et al., 2005).

Enzyme hydrolysis of NSPs has been known to improve the rheological properties of dough, bread volume, crumb firmness (and structure), dough machinability, stability, oven spring and shelf life (Martinez-AnAya \& Jimenez, 1997). The enzymes most widely used in the baking industry include: fungal $\alpha$-amylases, endoxylanases, lipolytic enzymes, glucose

\footnotetext{
* To whom correspondence should be addressed. Phone: +27-21-808 3511; fax: +27-21-808 3510; e-mail: mman@sun.ac.za
} 
oxidases, proteases, intermediate heat stable $\alpha$-amylases and glucoamylases (GOESAERT et al., 2009). Endoxylanases positively impact dough and bread properties (GoESAERT et al., 2005). AX degradation results in an increased dough stability, which includes the dough retaining its optimal volume for longer, improved resistance to mechanical stress, and prolonged oven rise (Courtin et al., 1999; 2001). The latter leads to a higher volume loaf with a finer, softer and more homogeneous crumb.

The bread making process mainly used in South-Africa (derived from the Chorleywood Bread Process, CBP) can be described as a "no-time" straight dough process. This method requires the incorporation of all the ingredients in the initial mixing step using a high speed mixer (MONDAL \& DATTA, 2008), prior to a short dough development time. This implies that enzymes are required to (i) either work more efficiently during dough development or (ii) be more stable at high temperatures, which would allow for substrate degradation during the first part of the baking process when the dough is still heating up.

Commercial enzyme preparations contain a mixture of enzymes, making it difficult to evaluate the effect of a specific enzyme activity. Thus, in the current study relatively pure enzyme preparations of the Trichoderma reesei endoxylanase (Xyn2) and endoglucanase (EgII) were obtained. The effect of these enzymes on the quality of bread loaves, made from commercial wheat flour, was evaluated on laboratory-scale, as well as commercial-scale. Commercial endoxylanase (Com-xyl) and a cellulose-xylanase cocktail (Cel-xyl) were included for comparison purposes. The effect of the pure and commercial enzymes was determined on laboratory and commercial-scale in terms of dough and bread quality characteristics (loaf weight, loaf height, crumb texture, crumb softness and slice brightness).

\section{Materials and methods}

\subsection{Enzymes}

Pure enzymes, i.e. Xyn2 (T. reesei xyn2, endoxylanase heterologously expressed in A. niger D15) and EgII (T. reesei egII, endoglucanase heterologously expressed in A. niger D15), were provided by the Department of Microbiology, Stellenbosch University (Stellenbosch, South Africa) (Rose \& VAN ZYL, 2002; 2008). Commercial enzymes included endoxylanase from A. niger (Com-xyl) (Anchor Yeast, Johannesburg, South Africa) and a cellulasexylanase cocktail from T. reesei (Cel-xyl) (River Biotech, Cape Town, South Africa). $\alpha$-Amylase from Aspergillus oryzae (Anchor Yeast, Johannesburg, South Africa) was included as part of the bread formulation; doughs containing only the $\alpha$-amylase was used as negative controls. All enzyme preparations were received as lyophilised samples and stored at $4{ }^{\circ} \mathrm{C}$.

\subsection{Enzyme activity assays}

Enzyme activity was measured using dinitrosalicylic acid (BAILEY et al., 1992). Endoxylanase, $\alpha$-amylase activity and endoglucanase activities were measured using $1 \%$ birchwood xylan (Roth, Karlsruhe, Germany), 0.1\% unmodified soluble wheat starch (soluble starch, SigmaAldrich, Germany) and $0.1 \%$ lichenan (Sigma-Aldrich), respectively. The release of reducing sugars was determined after an incubation period of $5 \mathrm{~min}$ at $40{ }^{\circ} \mathrm{C}$ using $0.05 \mathrm{M}$ sodium citrate buffer ( $\mathrm{pH}$ 5.0). Cellobiohydrolase activity was determined under the same conditions, but using $4 \mathrm{mM} p \mathrm{NPC}$ ( $p$-nitrophenyl $\beta$-D-cellobioside, Sigma-Aldrich) as the substrate 
(Den HaAn et al., 2007). The $p$-nitrophenol ( $p$-NP) released from $p$ NPC was detected spectrophotometrically at a wavelength of $405 \mathrm{~nm}$ after the addition of $1 \mathrm{ml}$ of $1 \mathrm{M} \mathrm{Na}_{2} \mathrm{CO}_{3}$ to raise the $\mathrm{pH}$ and terminate the reaction. All analyses were performed in triplicate.

\subsection{Flour quality analysis}

Moisture and ash contents were measured according to AACC Approved Methods 44-15A and $08-01 / 02$, respectively (AACC, 2000). The protein content was determined using a nitrogen analyser (Truspec ${ }^{\circledR}$ N Elemental Determinator, Leco, St. Joseph, Michigan, USA) according to the Dumas combustion method (AACC Approved Method 4630; AACC, 2000). Ethylenediamine-tetraacetic acid (EDTA) standard and tin foils were supplied by Leco Africa (Kempton Park, South Africa). Rheological measurements were carried out using AACC approved methods (AACC, 2000). Water absorption was determined using a Consistograph NG (Tripetteet Renaud, France) according to Method 54-50, as well as a Brabender Farinograph (Duisburg, Germany) (Method 54-21). The viscoelastic behaviour of the dough was determined (Method 54-30A) using an Alveograph MA 82 (Chopin, Tripette et Renaud, France) and optimum mixing time using a Mixograph (National Mfg Co., Lincoln, Nebraska, USA) (Method 54-40A). The presence of $\alpha$-amylase activity in the flour was determined using a Shakematic 1095 and a Falling Number 1500 (Perten Instruments AB, Sweden) (Method 56-81B).

\subsection{Laboratory scale baking test}

The optimised straight-dough bread making method was used [AACC Approved Method 1010B (AACC, 2000)]. Commercial white bread flour was used to prepare a 'lean' formulation, containing reduced levels of salt, fat and sugar (Table 1). Oven (Convecta 8, Macadams, South Africa) temperature and baking time were adjusted to $200^{\circ} \mathrm{C}$ and $26 \mathrm{~min}$, respectively.

Table 1. Bread making formulations used for the laboratory-scale and commercial-scale baking tests

\begin{tabular}{|c|c|c|c|}
\hline \multirow[t]{2}{*}{ Ingredients } & \multicolumn{2}{|c|}{ Formulations } & \multirow[t]{2}{*}{ Supplier } \\
\hline & $\begin{array}{l}\text { Laboratory } \\
100 \text { g loaf }\end{array}$ & $\begin{array}{l}\text { Commercial } \\
800 \mathrm{~g} \text { loaf }\end{array}$ & \\
\hline Flour (14\% mb) (\%) & 100 & 100 & Pioneer Foods, Paarl, SA \\
\hline Distilled water & Optimum & Optimum & -- \\
\hline Sugar $(\%)$ & 1 & 1 & -- \\
\hline Fresh compressed yeast (\%) & 1.8 & 2.6 & Anchor Yeast, Johannesburg, SA \\
\hline Shortening (fat) (\%) & 2 & 0.25 & $\begin{array}{l}\text { Chipkins Bakery Supply, Montague Gardens, } \\
\text { SA }\end{array}$ \\
\hline Salt $(\mathrm{NaCl})(\%)$ & 2 & 2 & Labchem, Johannesburg, SA \\
\hline Soy flour (\%) & 0.5 & 0.2 & Impilo Products Pretoria, SA \\
\hline Ascorbic acid (ppm) & 80 & 80 & Labchem, Johannesburg, SA \\
\hline Fungal $\alpha$-amylase (ppm) & 7 & 7 & Anchor Yeast, Johannesburg, SA \\
\hline
\end{tabular}

mb: moisture basis 
The effect of each enzyme was evaluated individually at different concentration levels: Xyn2 (10, 24 and 40 ppm), EgII (40, 80 and 150 ppm), Com-xyl (5, 12, and 20 ppm) and the Cel-xyl cocktail $(3,5$, and 8 ppm). Ascorbic acid and all enzymes were made up to predetermined concentrations (stock solutions) using distilled water.

The characteristics of the dough were evaluated after mixing and bread loaf characteristics such as weight $(\mathrm{g})$, height $(\mathrm{cm})$, crumb texture and softness assessed. Texture analysis of the bread was performed after cooling and $24 \mathrm{~h}$ of storage at $22^{\circ} \mathrm{C}$. Crumb texture was assessed using a C Cell digital image analysis system (Colibre Control International, UK). The total slice area (pixels), maximum height (pixels), number of cells, holes, volume of cells and holes, and slice brightness (pixels) were determined. Immediately after digital imaging the same bread slices were used for crumb softness measurements using a Zwick Roell Material Testing Machine (Model Z005, Zwick Roell, Germany). The softness of the bread slices were recorded in Newton on days 1, 3, 5, and 6 according to AACC method 74-09.

\subsection{Commercial-scale baking tests}

A commercial (800 g loaf) "no-time" straight dough baking test was used with a lean formulation (Table 1), similar to the laboratory-scale method. The Xyn2 (5 and 20 ppm), EgII (40 and $150 \mathrm{ppm}$ ), Com-xyl (5 and $20 \mathrm{ppm}$ ) and the Cel-xyl cocktail (3 and 8 ppm) were added. The dough was mixed, covered with a plastic dome, and allowed to rest ( $5 \mathrm{~min}$ ). The dough was divided into two equal portions and scaled to yield a final bread mass of $800 \mathrm{~g}$. The dough was covered with a plastic dome, allowed to rest at ambient temperature for 5 min and passed through a moulder. The dough was placed seam side down in bread pans, proofed in a fermentation cabinet for 52 min at $40{ }^{\circ} \mathrm{C}$ [80\% relative humidity (RH)] and baked in a pre-heated convection oven for $26 \mathrm{~min}$ at $200{ }^{\circ} \mathrm{C}$. Loaves were removed from the pans, weighed, and left to cool for $1 \mathrm{~h}$ at room temperature. They were stored in plastic bags for $24 \mathrm{~h}$ at $22{ }^{\circ} \mathrm{C}$, after which quality evaluations were performed.

The measurements for proof height, bread weight, height and volume were taken as an average of the two loaves baked from the same dough. Crumb grain characteristics were recorded using a C Cell digital image analysis system. Crumb softness was performed with the Zwick Roell Material Testing Machine (Model Z005, Zwick Roell, Germany) on one loaf on day $1\left(24 \mathrm{~h}\right.$ storage at $\left.22^{\circ} \mathrm{C}\right)$ and on the second loaf on day 4 .

\subsection{Statistical analysis}

Statistical analysis was performed using STATISTICA version 8. Analysis of variance (ANOVA) was performed to compare average measurements between samples and to determine absolute differences. Analysis of covariance (ANCOVA) was used to compensate for the effect of dough temperature. Pearson correlations were calculated to determine relationships between continuous measurements. Fisher least significance difference (LSD) post-hoc testing was used. All references to significant differences indicate statistical significant difference at $\mathrm{P}<0.05$.

\section{Results and discussion}

\subsection{Commercial wheat flour quality}

The flour used in this study was an intermediate strength commercial white bread flour (Table 2), ideal for testing the effect of enzymes. 
Table 2. Quality attributes of the commercial white bread flour used for the baking tests

\begin{tabular}{lc}
\hline Quality attribute & Results $^{\#}$ \\
\hline Moisture (\%) & $14.0 \pm 0.09$ \\
Ash (dry weight) (\%) & $0.90 \pm 0.01$ \\
Protein (12\% mb) (\%) & $9.9 \pm 0.13$ \\
Consistograph & \\
Water absorption (14\% mb) (\%) & $62.2 \pm 1.07$ \\
Tolerance (s) & $267 \pm 25.23$ \\
Alveograph & \\
Tenacity (P) (mm) & $79 \pm 3.21$ \\
Dough extensibility (L) (mm) & $81 \pm 5.03$ \\
Deformation energy (W) (x10 ${ }^{-4}$ Joules) & $203 \pm 11.93$ \\
Curve configuration ratio (P/L) & $0.99 \pm 0.07$ \\
Farinograph & \\
Water absorption (14\% mb) (\%) & \\
Dough development time (min) & $59.0 \pm 0.1$ \\
Stability (min) & $2.2 \pm 0.15$ \\
Mixograph & $8.6 \pm 0.15$ \\
Water absorption (\%) & \\
Peak time (min) & \\
Falling number & $59.74 \pm 0.33$ \\
Falling number (s) & $3.52 \pm 0.04$ \\
\hline
\end{tabular}

\#: Mean \pm SD (standard deviation); mb: moisture basis

\subsection{Enzyme activity}

The activities of the different enzyme preparations were determined (Table 3). Xyn2 displayed only endoxylanase activity. EgII displayed endoglucanase and limited endoxylanase activity. Com-xyl displayed endoxylanase and amylase activity (against boiled starch, negligible activity against raw starch at $40{ }^{\circ} \mathrm{C}$ and $60{ }^{\circ} \mathrm{C}$ ). Cel-xyl exhibited activity against all the substrates tested indicating the presence of a cocktail of enzymes. The level of enzyme additions (ppm) was converted to enzyme activity in nkat $/ \mathrm{kg}$ of flour to allow comparison of enzyme activities in the different baking tests (Table 4).

Table 3. The activity of the enzymes (nkat/mg enzyme) measured against different substrates

\begin{tabular}{|c|c|c|c|c|c|c|}
\hline \multirow{3}{*}{ Enzyme } & \multicolumn{2}{|c|}{ Cellulose } & \multirow{3}{*}{$\begin{array}{c}\text { Xylan } \\
\text { Birchwood } \\
\left(40^{\circ} \mathrm{C}\right)\end{array}$} & \multicolumn{3}{|c|}{ Starch } \\
\hline & \multirow{2}{*}{$\begin{array}{c}\text { Lichenan }^{1} \\
\left(40^{\circ} \mathrm{C}\right)\end{array}$} & \multirow{2}{*}{$\begin{array}{l}\mathrm{pNPC}^{2} \\
\left(40^{\circ} \mathrm{C}\right)\end{array}$} & & \multirow{2}{*}{$\begin{array}{c}\text { Raw } \\
\left(40^{\circ} \mathrm{C}\right)\end{array}$} & \multicolumn{2}{|c|}{ Boiled } \\
\hline & & & & & $\left(60^{\circ} \mathrm{C}\right)$ & $\left(40^{\circ} \mathrm{C}\right)$ \\
\hline Com-xyl ${ }^{3}$ & 0 & 0 & $96 \pm 2.92$ & $1.42 \pm 0.06$ & $1.77 \pm 0.32$ & $42 \pm 1.48$ \\
\hline Xyn $2^{4}$ & 0 & 0 & $103 \pm 0.37$ & 0 & 0 & 0 \\
\hline $\mathrm{Cel}_{-x y 1^{5}}$ & $58 \pm 4.82$ & $0.76 \pm 0.028$ & $128 \pm 8.98$ & $1.0 \pm 0.34$ & $1.63 \pm 0.25$ & $9.98 \pm 0.15$ \\
\hline $\mathrm{EgII}^{6}$ & $26 \pm 1.66$ & 0 & $2.97 \pm 0.04$ & 0 & 0 & 0 \\
\hline
\end{tabular}

${ }^{1}$ : Natural form of cellulose; ${ }^{2}$ : $p$-nitrophenyl $\beta$-D-cellobioside for cellobiohydrolase activity

3. Commercial enzyme with endoxylanase from Aspergillus niger; ${ }^{4}$ : xyn $2-T$. reesei endoxylanase

${ }^{5}$ : Commercial cellulose-xylanase cocktail; ${ }^{6}$ : EgII - T. reesei endoglucanase; ${ }^{7}$ : Mean \pm standard deviation 
Table 4. Concentrations of enzymes used, in the respective baking tests, in ppm and corresponding activity in $\mathrm{nkat} / \mathrm{kg}$

\begin{tabular}{|c|c|c|c|c|c|c|c|c|c|c|c|}
\hline \multirow{3}{*}{$\begin{array}{l}\text { Activity } \\
\text { ppm }\end{array}$} & \multicolumn{11}{|c|}{ Enzyme additions in ppm } \\
\hline & \multirow{2}{*}{$\begin{array}{c}\text { Control } \\
0\end{array}$} & \multicolumn{2}{|c|}{$\mathrm{Xyn} 2^{1}$} & \multicolumn{2}{|c|}{ Xyn2 } & \multicolumn{2}{|c|}{ Com-xyl } & \multicolumn{2}{|c|}{ EgII } & \multicolumn{2}{|c|}{ Cel-xyl } \\
\hline & & 10 & 40 & 5 & 20 & 5 & 20 & 40 & 150 & 3 & 8 \\
\hline & \multicolumn{11}{|c|}{ Enzyme activity in nkat/kg } \\
\hline & Control & \multicolumn{2}{|c|}{ Xyn $2^{1}$} & \multicolumn{2}{|c|}{ Xyn2 } & \multicolumn{2}{|c|}{ Com-xyl } & \multicolumn{2}{|c|}{ EgII } & \multicolumn{2}{|c|}{ Cel-xyl } \\
\hline Endoxylanase & 0 & 1030 & 4100 & 515 & 2050 & 480 & 1920 & 100 & 450 & 390 & 1030 \\
\hline$\alpha$-Amylase & 0 & 0 & 0 & 0 & 0 & 0 & 0 & 0 & 0 & 3 & 8 \\
\hline Endoglucanase & 0 & 0 & 0 & 0 & 0 & 7 & 28 & 1100 & 4030 & 176 & 470 \\
\hline
\end{tabular}

1: Xyn2 concentrations used for the laboratory-scale baking tests

\subsection{Baking tests}

Effects of the enzyme additions on dough properties and bread quality characteristics are summarised in Table 5. Only results where significant effects were observed are shown. As expected, no significant differences in bread weight were observed between the negative control and the enzyme treated counterparts.

Table 5. Summary of the effect of enzymes on dough and bread characteristics with laboratory and commercialscale tests

\begin{tabular}{|c|c|c|c|c|c|}
\hline \multirow[b]{2}{*}{ Enzymes } & \multicolumn{2}{|c|}{ Dough characteristics } & \multirow{2}{*}{$\begin{array}{l}\text { Bread volume* } \\
\text { Commercial- } \\
\text { scale }\end{array}$} & \multirow{2}{*}{$\begin{array}{l}\text { Crumb texture } \\
\text { Commercial- } \\
\text { scale }\end{array}$} & \multirow{2}{*}{$\begin{array}{l}\text { Crumb softness } \\
\text { Laboratory scale }\end{array}$} \\
\hline & Laboratory scale & $\begin{array}{l}\text { Commercial- } \\
\text { scale }\end{array}$ & & & \\
\hline Xyn2 (ppm) & Dry and firm & $\begin{array}{l}\text { Sticky at } 5 \text {, } \\
20 \text { ppm }\end{array}$ & Inc at 20 & Dec at 5, $20 \mathrm{ppm}$ & Inc at $40 \mathrm{ppm}$ \\
\hline EgII (ppm) & $\mathrm{NE}$ & $\mathrm{NE}$ & Inc at 150 & Dec at $150 \mathrm{ppm}$ & Inc at $40 \mathrm{ppm}$ \\
\hline Com-xyl (ppm) & Sticky and soft & $\mathrm{NE}$ & Inc at 20 & Dec at $5 \mathrm{ppm}$ & Inc at 5,20 ppm \\
\hline Cel-xyl (ppm) & $\begin{array}{l}\text { Sticky, difficult } \\
\text { to handle }\end{array}$ & $\begin{array}{l}\text { Sticky at } 3,8 \\
\text { ppm }\end{array}$ & Inc at $3,8 \mathrm{ppm}$ & $\mathrm{NE}$ & Inc at $3 \mathrm{ppm}$ \\
\hline
\end{tabular}

* Determined with C Cell

Inc: increase; Dec: decrease; NE: no significant effect detected

The Xyn2 and EgII did not detrimentally influence the dough properties in the laboratoryscale testing. On the other hand both the commercial enzymes, Com-xyl and Cel-xyl, produced a sticky dough during the laboratory-scale baking tests. The use of Xyn2 at 5 and $20 \mathrm{ppm}$ and Cel-xyl at 3 and $8 \mathrm{ppm}$ resulted in the development of a sticky dough in the commercial-scale tests.

None of the enzyme additions had a significant effect on the bread volume or bread crumb texture in laboratory-scale testing (Table 5). Although not significant, a finer crumb texture (measured with C Cell) resulted from the addition of Xyn2 and EGII in the laboratoryscale testing. Compared to the negative control, both Xyn2 and Com-xyl significantly 
increased bread height in the laboratory-scale baking tests (Fig. 1). An increase in crumb softness (measured after $24 \mathrm{~h}$ of storage) was observed for all enzymes at some of the enzyme addition levels.

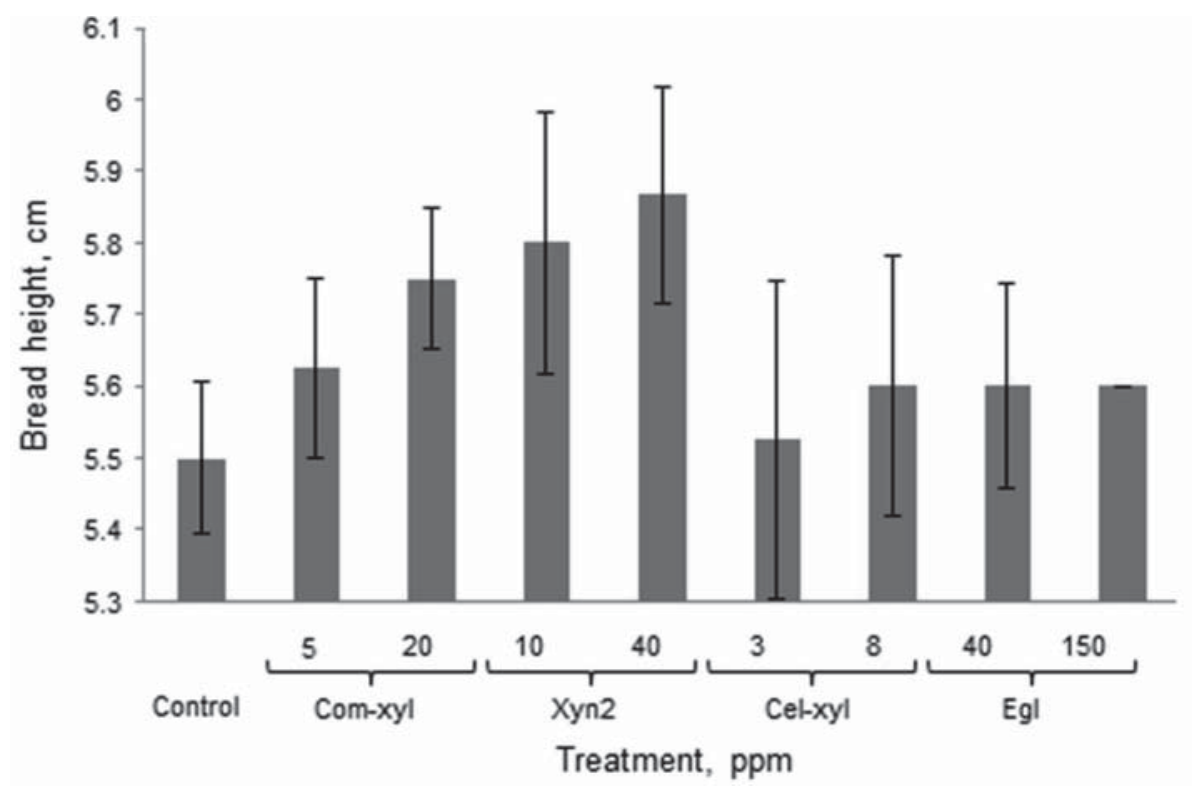

Fig. 1. Differences between the average bread heights $(\mathrm{cm})$ measured manually for the laboratory scale tests determined with analysis of variance (ANOVA) for each respective enzyme. Error bars denote 0.95 confidence intervals (Com-xyl: commercial xylanase; Xyn2: endoxylanase from T. reesei; Cel-xyl: cellulase and xylanase cocktail; EgII: endoglucanase from $T$. reesei)

Significant increases in bread height of the commercial loaves were observed for Xyn2 (20 ppm) and EgII (150 ppm) (Fig. 2B, D). Digital images (C Cell) similarly showed an increase in bread heights for additions of Xyn2 at $20 \mathrm{ppm}$ and EgII at $150 \mathrm{ppm}$ (Fig. 2E). Results from C Cell measurements indicated a significant increase in bread volume with the addition of Xyn2 (20 ppm), EgII (150 ppm), Com-xyl (20 ppm) and Cel-xyl (3 and 8 ppm). This corresponded to the increase in bread height observed for the pure enzymes. The enzymes, Xyn2 and EgII at concentrations of $20 \mathrm{ppm}$ and $150 \mathrm{ppm}$, respectively, resulted in open crusts. Commercial-scale testing showed no improvement in bread crumb texture or crumb softness.

On laboratory-scale the formulations containing EgII and Cel-xyl (at all concentrations) as well as Xyn2 (40 ppm), indicated a significant increase in slice brightness when compared to the negative control (Fig. 3A). However, for the commercial-scale baking tests the addition of enzymes did not increase the slice brightness (Fig. 3B). 

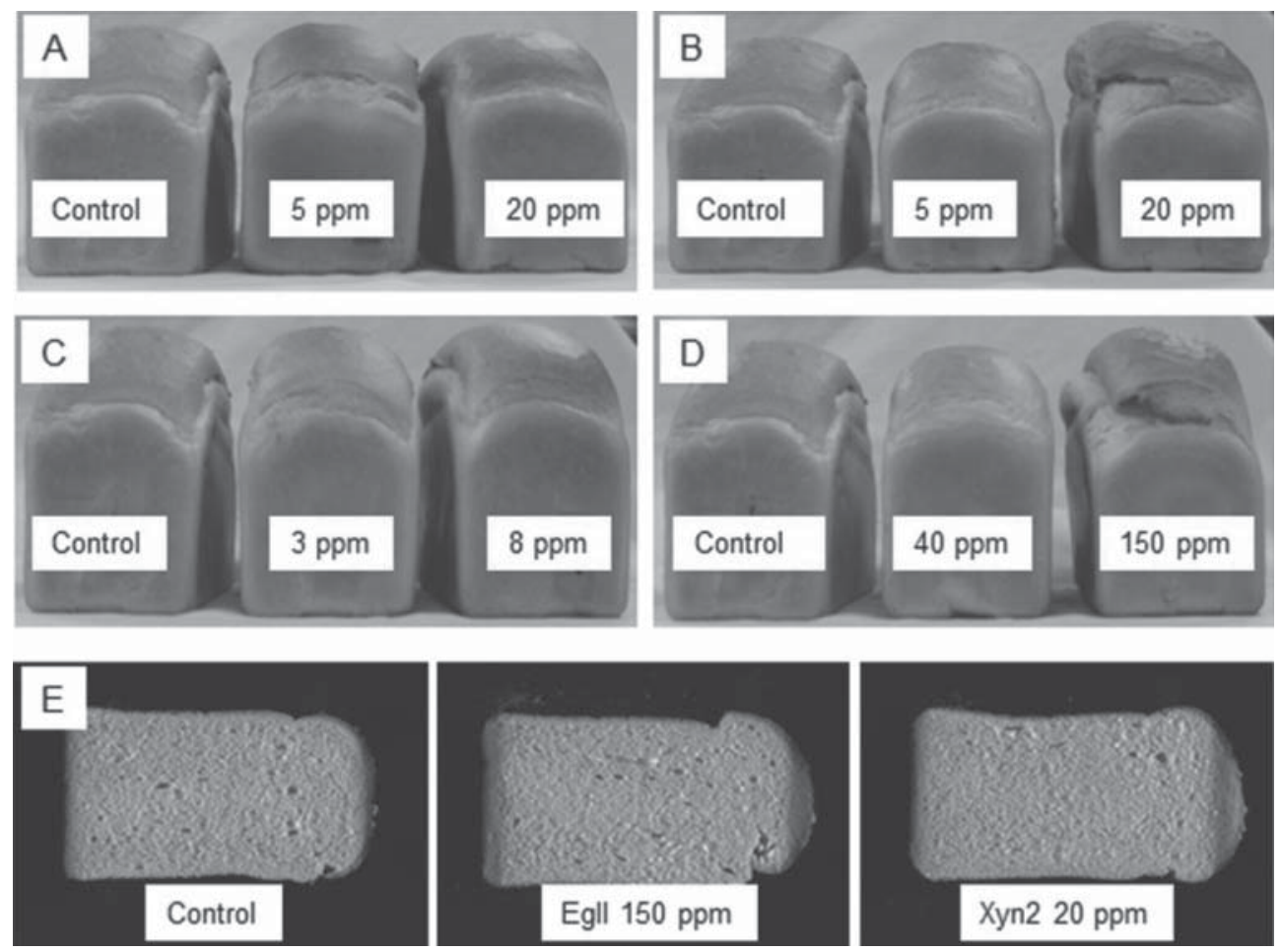

Fig. 2. Bread loaves of the commercial-scale tests comparing the negative control to A) Com-xyl, B) Xyn2, C) Cel-xyl and D) EgII. E) Digital images of bread slices obtained with the C Cell with the negative control compared to EgII at $150 \mathrm{ppm}$ and $\mathrm{Xyn} 2$ at $20 \mathrm{ppm}$

For the commercial-scale baking tests cell area, measured by digital imaging (C Cell), significantly increased when Xyn2 was used at $20 \mathrm{ppm}$ (Fig. 4A). The number of cells significantly decreased with the use of Xyn2 (5 and 20 ppm) and Com-xyl (5 ppm) (Fig. 4B). Cell volume significantly increased with the addition of Xyn2 (20 ppm) and EgII (150 ppm) (Fig. 4C).

Evaluation of baking enzymes is usually performed by means of laboratory-scale baking tests (10-250 g flour) using the straight or sponge dough bread making methods (HARADA et al., 2000, 2005; JiAng et al., 2005; ShaH et al., 2006; CABALLERo et al., 2007). Generally, only commercially available enzymes are evaluated. The commercial Com-xyl, used in this study, was shown to contain xylanase, cellulase and $\alpha$-amylase. The Cel-xyl displayed xylanase, endoglucanase, cellobiohydrolase and $\alpha$-amylase activities. This mixture of activities makes it difficult to assign the effect on a specific bread quality characteristic to a specific enzyme activity. However, Xyn2 displayed only endoxylanase activity and the EgII displayed endoglucanase and limited endoxylanase activity. Therefore, these two pure enzymes were compared to the commercial enzymes and a negative control (containing only limited $\alpha$-amylase as part of the bread making formulation). 


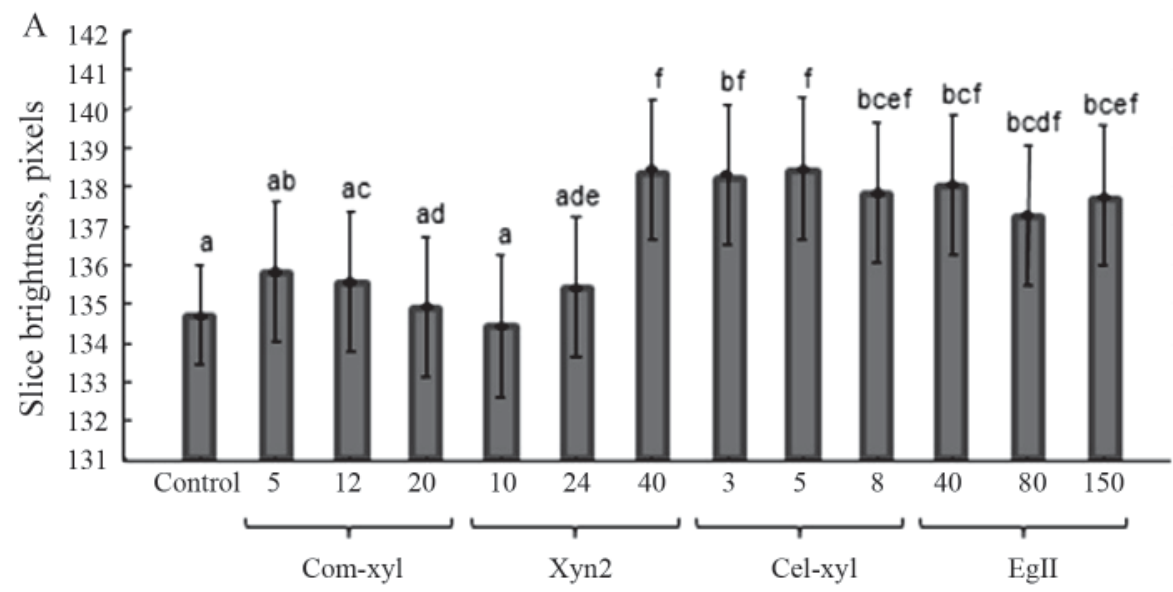

Treatment, ppm

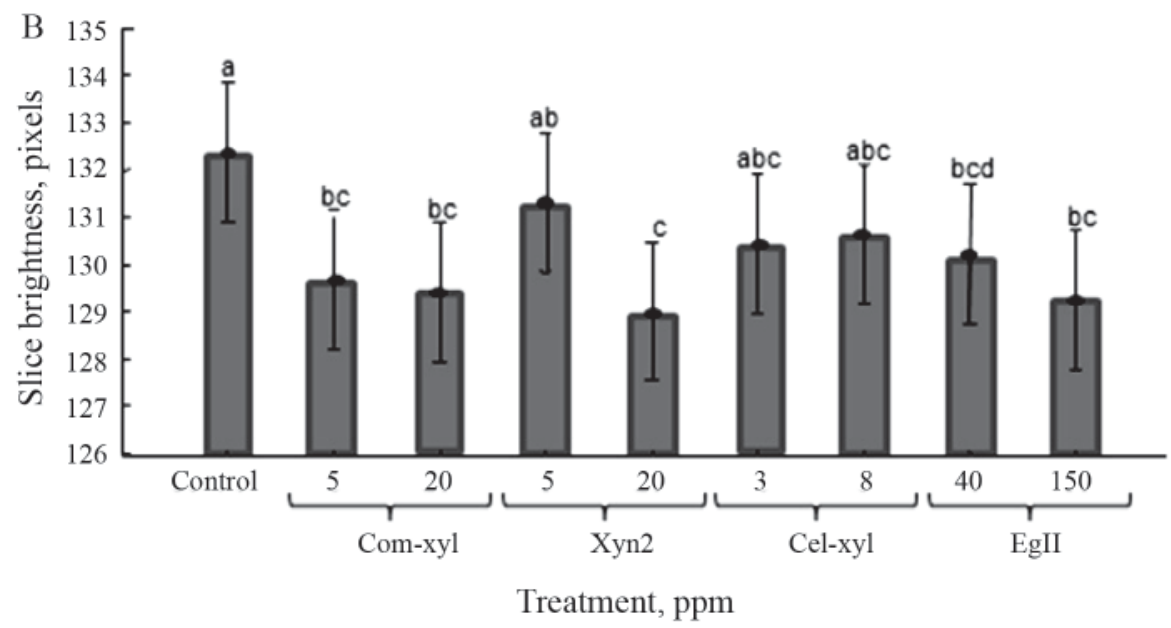

Fig. 3. Differences between the average slice brightness results obtained for the A) laboratory and B) commercialscale tests determined with analysis of variance (ANOVA). Results shown are the slice brightness for each enzyme at the respective concentration levels. Error bars denote 0.95 confidence intervals. Different letters indicate significant differences obtained from LSD analysis

The addition of Xyn2 and EgII, exhibiting only endoxylanase and endoglucanase activity, respectively, did not have a negative impact on the dough characteristics (Table 5). Formulations containing Xyn2 did result in a sticky dough in the commercial-scale baking test. It has been reported that, although fungal derived endoxylanases (from A. niger) can result in a sticky dough, the dough often recover well (HiLLE, 2005). The high speed mixer resulted in high energy input, leading to an increase in dough temperature. This would have affected the enzyme efficiency. The mixer might also have contributed to shearing of the starch, xylan, or cellulose resulting in increased substrate accessibility and increased hydrolysis. The Cel-xyl resulted in a sticky dough, probably due to the additional $\alpha$-amylase 
activity. The degradation of starch would have led to the release of soluble maltose and glucose which could have contributed to the sticky effect.

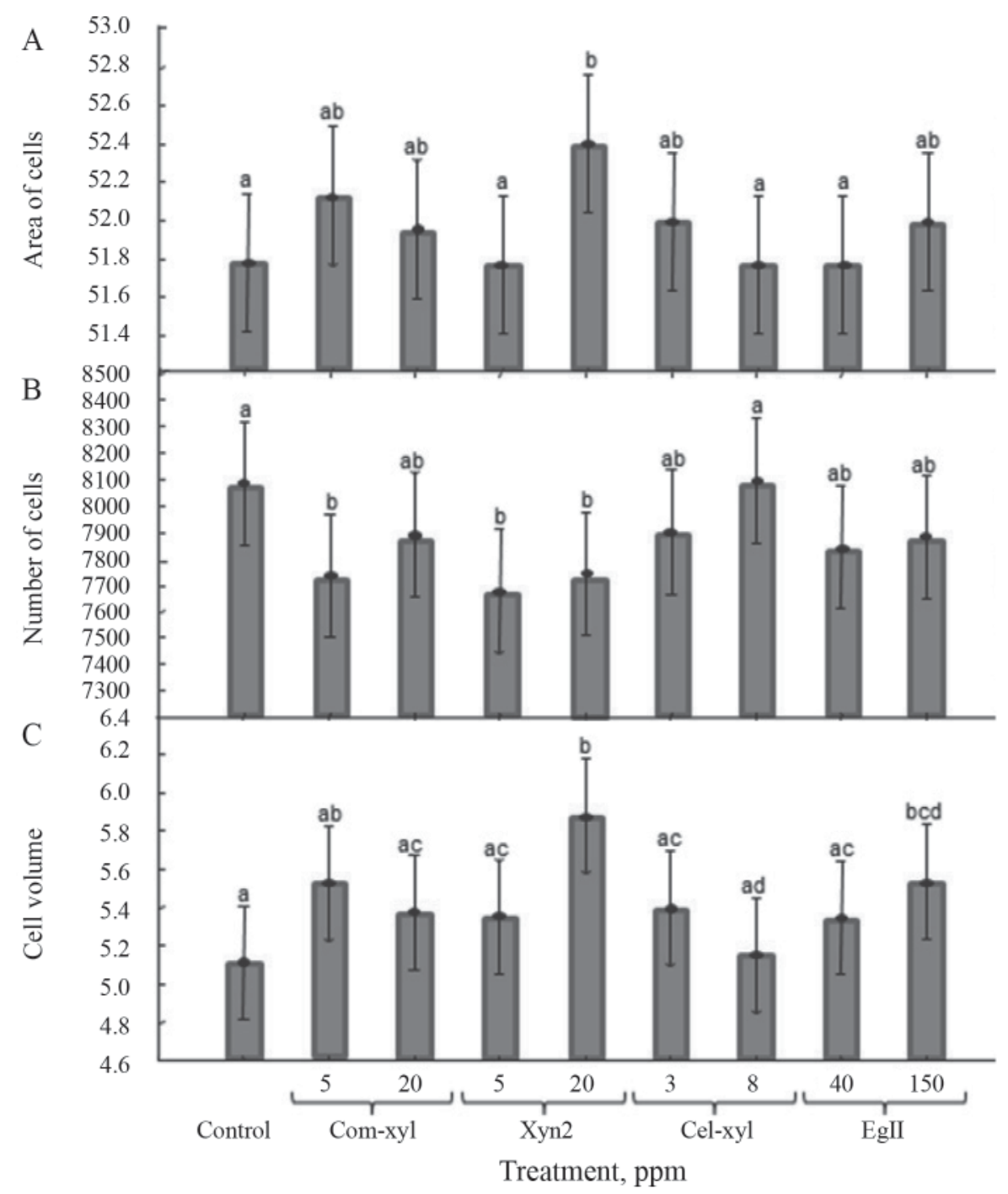

Fig. 4. Differences between the A) area, B) number and C) volume of cells determined by analysis of variance (ANOVA) for the commercial scale tests. Error bars denote 0.95 confidence intervals. Different letters indicate significant differences obtained from LSD analysis

The significant increase in bread volume observed with the majority of enzyme additions for the commercial-scale testing (Table 5) confirmed that high levels of endoxylanase activity are required for an increase in bread volume when endoglucanase activity is absent. Xyn2 had a significant negative influence on the crumb texture when used at $20 \mathrm{ppm}$ and therefore xylanase levels used to improve bread volume should be carefully monitored to ensure 
acceptable crumb texture. The levels of both the pure enzymes must also be reduced to obtain a bread loaf with a more acceptable uniform shape (preventing open crusts).

Fungal enzymes function optimally between 40 and $80{ }^{\circ} \mathrm{C}$ (BaLdRain \& Valaskova, 2008). Therefore, the effect of the baking enzymes becomes more prominent during proofing and baking; often leading to an increased bread height. In the laboratory-scale baking tests the use of Xyn2 at 10 and $40 \mathrm{ppm}$ resulted in an increased loaf height (Fig. 1; Table 4). Xyn2 at $10 \mathrm{ppm}(1030 \mathrm{nkat} / \mathrm{kg})$ resulted in a larger increase in bread height compared to the Comxyl (20 ppm), which had to be added at a higher concentration $(1920 \mathrm{nkat} / \mathrm{kg})$ to obtain a similar effect. Endoxylanases are known to increase bread height (HAMER, 1995; Poutanen, 1997; Courtin et al., 1999; Hille, 2004, 2005) and when used in conjunction with cellulases an additional increase in loaf height can be expected (Aristidou \& PentTilä, 2000). Yet, additions of EgII and the Celxyl, both containing endoglucanase and endoxylanase activities, did not contribute to bread height on laboratory scale. The EgII, however, did result in an increase in bread height in the commercial scale tests.

Most of the formulations significantly increased crumb softness (Table 5) in the laboratory-scale baking tests, similar to what had been reported in previous studies (HAMER, 1995; Martinez-Anaya \& Jimenez, 1997; Poutanen, 1997; Harada et al., 2000; Hille, 2004, 2005; Harada et al., 2005; JiANG et al., 2005; ShaH et al., 2006; CABAllero et al., 2007). To obtain an increase in crumb softness, Xyn2 was required at $4100 \mathrm{nkat} / \mathrm{kg}$ activity, whereas EgII was required at a concentration of $1100 \mathrm{nkat} / \mathrm{kg}$ (contain thirty times less endoxylanase activity than the Xyn2 at $40 \mathrm{ppm}$ ), indicating that less endoxylanase activity is required when endoglucanase activity is also present.

None of the enzymes significantly increased crumb softness in the commercial-scale breadmaking tests. HILLE (2005) reported a considerable increase in softness observed on days 4 and 7 of storage. In the present study enzyme concentrations might not have been optimal for an increased shelf-life. While $\alpha$-amylases in general retard bread staling (MILLER et al., 1953; Bowles, 1996; Linko et al., 1997; Poutanen, 1997; Gray \& Bemiller, 2003; Goesaert et al., 2005; CABALLERo et al., 2007; GoEsAERT et al., 2009), the levels of $\alpha$-amylases used in this study were sub-optimal to emphasise the effect of the other enzymes on the dough and bread quality characteristics. The crumb softness can thus be enhanced with an increase in $\alpha$-amylases concentration.

In the laboratory-scale baking tests Cel-xyl and EgII significantly increased slice brightness, independent of concentrations used, whereas Xyn2 required a concentration of 40 ppm to be effective. This was due to smaller or shallower cells (holes) having formed, which resulted in a finer crumb texture with smaller shadows on the bread slice and therefore leading to an overall increase in slice brightness. None of the enzyme concentrations used had a significant effect on the texture of the bread crumb. This was seen in the number, area, or volume of the cells not being significantly affected. The enzyme additions had a negative or no effect on slice brightness in the commercial-scale baking tests. This was expected due to the observed coarse crumb texture, which was a result of the increased cell area and volume as measured with the C Cell. A decrease in slice brightness was due to larger/deeper cells reflecting larger shadows. Endoxylanases used at lower levels may result in an improved crumb texture and subsequent increased slice brightness. 


\section{Conclusions}

This study demonstrated that low levels of endoxylanase activity may benefit bread height and volume without affecting slice brightness detrimentally during commercial scale bread production. The addition of endoglucanases enables the use of less endoxylanases to obtain similar results. The contribution of a specific enzyme activity is usually masked by the effect of the other enzymes present in the commercial enzyme preparations. Pure enzymes (compared to cocktails) enable the effect of a specific enzyme to be more prominent. The A. niger strain, used for the production of Xyn2 and EgII, was constructed in such a way that high level of enzyme production is possible without the addition of inducers or expensive media. It should be possible to produce high levels of Xyn2 and EgII at the same cost (or even less) as Com-xyl and Cel-xyl. The use of pure enzymes could become beneficial to the industry for the improvement of specific bread quality characteristics.

Authors thank the NRF (FA2006031500013) and PA and Alize Malan Trust for funding; Pioneer Foods and Baking, Paarl for their kind provision of wheat flour; Lorraine Bezuidenhout (Anchor Yeast, Johannesburg) for the provision of yeast; River Biotech, Cape Town for supply of commercial enzymes; Prof Martin Kidd (Centre for Statistical Consultation, Stellenbosch University) for statistical analysis; Arie Wessels and David Howard (Pioneer Foods, Paarl); and Dr Jan Hille (DSM Baking Enzymes, Delft, Netherlands) for their valuable advice.

\section{References}

AACC (2000): Approved methods of the AACC, $10^{\text {th }}$ ed. American Association of Cereal Chemists, AACC International, St. Paul, Minnesota, USA

Aristidou, A. \& Penttilä, M. (2000): Metabolic engineering applications to renewable resource utilization. Curr. Opin. Biotechnol., 11, 187-198.

Bailey, M.J., Biely, P. \& Poutanen, K. (1992): Interlaboratory testing of methods for assay of xylanase activity. J. Biotechnol., 23, 257-270.

Baillet, E., Downey, G. \& Tuohy, M. (2003): Improvement of texture and volume in white bread rolls by incorporation of microbial hemicellulase preparations. -in: Courtin, C.M., Veraverbeke, W.S. \& Delcour, J.A. (Eds) Recent advances in enzymes in grain processing. Laboratory of Food Chemistry, Katolieke Universiteit Leuven, Leuven, Belgium. pp. 255-259.

Baldrain, P. \& Valaskova, V. (2008): Degradation of cellulose by basidiomycetous fungi. FEMS Microbial Rev., $32,501-521$

Bowles, L.K. (1996): Amylolytic enzymes. -in: HeBedA, R.E. \& ZoBel, H.F. (Eds) Baked goods freshness, technology, evaluation and inhibition of staling. Marcel Dekker Inc., New York, USA. pp. 105-129.

Caballero, P.A., Gómez, M. \& Rosell, C.M. (2007): Improvement of dough rheology, bread quality and bread shelf-life by enzymes combination. J. Food Eng., 81, 42-53.

Courtin, C.M., Roelants, A. \& Delcour, J.A. (1999): Fractionation-reconstitution experiments provide insight into the role of endoxylanases in bread-making. J. Agr. Food Chem., 47, 1870-1877.

Courtin, C.M., Gelders, G.C. \& Delcour, J.A. (2001): The use of two endoxylanases with different substrate selectivity provides insight into the functionality of arabinoxylans in wheat flour bread making. Cereal Chem., 78, 564-571.

Courtin, C.M. \& Delcour, J.A. (2002): Arabinoxylans and endoxylanases in wheat flour bread-making. J. Cereal Sci., 35, 225-243.

Den HaAn, R., Rose, S.H., Lynd, L.R. \& VAn ZyL, W.H. (2007): Hydrolysis and fermentation of amorphous cellulose by recombinant Saccharomyces cerevisiae. Metab. Eng., 9(1), 87-94.

Goesaert, H., Briss, K., Veraverbeke, W.S., Courtin, C.M., Gebruers, K. \& Delcour, J.A. (2005): Wheat flour constituents: how they impact bread quality, and how to impact their functionality. Trends Food Sci. Tech., 16, $12-30$.

Goesaert, H., Slade, L., Levine, H. \& Delcour, J.A. (2009): Amylases and bread firming - an integrated view. J. Cereal Sci., 50, 345-352. 
Gray, J.A. \& Bemiller, J.N. (2003): Bread staling: molecular basis and control. Compr. Rev. Food Sci. Food Safety, $2,1-21$.

Hamer, R.J. (1995): Enzymes in the baking industry. -in: Tucker, G.A. \& Woods, L.F.J. (Eds) Enzymes in food processing, $2^{\text {nd }}$ ed. Blackie Academic and Professional. Glasgow, UK, pp. 191-222.

Harada, O., Lysenko, E.D. \& Preston, K.R. (2000): Effects of commercial hydrolytic enzymes additives on Canadian short process bread properties and processing characteristics. Cereal Chem., 77, 70-76.

Harada, O., Lysenko, E.D., Edwards, N.M. \& Preston, K.R. (2005): Effects of commercial hydrolytic enzymes additives on Japanese-style sponge and dough bread properties and processing characteristics. Cereal Chem., $82,314-320$.

Hille, J.D.R. (2004): Hemicellulases and their synergism in breadmaking. Cereal Food World, 49, 283-286.

Hitle, J.D.R. (2005): Enzymes in baking. Innov. Food Technol., Feb., 56-58.

JiANG, Z., LI, X., YANG, S., LI, L. \& TAN, S. (2005): Improvement of the breadmaking quality of wheat flour by the hyperthermophilic xylanase B from Thermotoga maritima. Food Res. Int., 38(1), 37-43.

Linko, Y-Y., Javanainen, P. \& Linko, S. (1997): Biotechnology of bread baking. Trends Food Sci. Tech., 8, 339-344.

Martinez-Anaya, M.A. \& Jimenez, T. (1997): Functionalities of enzymes that hydrolyse starch and non-starch polysaccharide in bread making. Z. Lebensm. Unters. F. A., 205, 209-214.

Miller, B.S., Johnson, J.A. \& PALmer, D.L. (1953): A comparison of cereal, fungal and bacterial alpha-amylase as supplements for bread making. Food Technol., 7, 38. (-ref: Gray \& BemilLer, 2003).

Mondal, A. \& DatTA, A.K. (2008): Bread baking - a review. J. Food Eng., 86, 465-474.

Poutanen, K. (1997): Enzymes: an important tool in the improvement of the quality of cereal foods. Trends Food Sci. Tech., 8, 300-306.

Rose, S. \& VAn ZyL, W. (2002): Constitutive expression of the Trichoderma reesei $\beta-1,4$-xylanase gene (xyn2) and the $\beta-1,4$-endoglucanase gene (EgII) in Aspergillus niger in molasses and defined glucose media. Appl. Microbiol. Biotechnol., 58, 461-468.

Rose, S.H. \& VAN ZYL, W.H. (2008): Exploitation of Aspergillus niger for the heterologous production of cellulases and hemicellulases. Open Biotechnol. J., 2, 167-175.

Shah, A.R., Shah, R.K. \& Madamwar, D. (2006): Improvement of the quality of whole wheat bread by supplementation of xylanase from Aspergillus foetidus. Bioresource Technol., 97, 2047-2053. 